\title{
The Influence of Microclimatic Ammonia Changes in Closed House on Broiler's Performance in Dry Season
}

\author{
Ica Putri Angkeke, Teysar Adi Sarjana* and Edjeng Suprijatna \\ Poultry Production Laboratory, Faculty of Animal and Agricultural Sciences, Diponegoro University \\ e-mail : teysar_adi@undip.ac.id
}

\begin{abstract}
This research aims at investigating the impact of microclimatic ammonia change on Broiler's performance in closed house during dry season. Seven hundred and twenty broiler's with their initial weight of $49.29 \pm 1.13$ grams are kept in a $60 \times 12 \mathrm{~m}^{2}$ cage. The research consists of 4 treatments and 6 experiment units. The microclimatic ammonia change is measured at a distance of $0,1 / 4,1 / 2$, and $3 / 4$ of closed house's length from the inlet. The parameters observed are feed consumption, body weight gain (BWG), feed convertion ratio (FCR), performance index (PI) and Income Over Feed Cost (IOFC). The obtained data are subjected to analysis of variance and several data related to microclimate ammonia and heat stress index (HSI) are also their correlation to find out their correlation with the broiler's performance. The research results indicate that the microclimatic ammonia change significantly reduces Broiler's performance The results showed that ammonia microclimatic significant can changes reduced broiler performance, this refers to the FCR value, a decrease of feed consumption, BWG, PI and IOFC significantly $(P \leq 0.05)$ starting from $1 / 4$ length of addition from the inlet.The correlation analysis result shows a negative, significant correlation between performance with ammonia, while HSI does not show any correlation with the observed parameters. The conclusion of this research is that the increase in microclimatic ammonia at increasingly further distance from the inlet decreases Broiler's performance in the dry season.

Keywords: microclimatic ammonia, closed house, broiler's's performance, dry season
\end{abstract}

\begin{abstract}
Abstrak. Penelitian bertujuan untuk mengkaji dampak perubahan mikroklimatik amonia terhadap performans ayam broiler dalam kandang closed house di musim kemarau. Tujuh ratus dua puluh ayam broiler dengan bobot badan awal 49,29 $\pm 1,13$ gram dipelihara pada kandang berukuran $60 \times 12 \mathrm{~m}^{2}$. Penelitian ini terdiri dari 4 perlakuan dan 6 unit percobaan. Perubahan mikroklimatik amonia diukur pada jarak0, 1/4, 1/2, dan 3/4 panjang closed house dari inlet. Parameter yang diamati adalah konsumsi pakan, pertambahan bobot badan (PBB), feed convertion ratio (FCR), indeks performans (IP) dan Income Over Feed Cost (IOFC). Data yang diperoleh dianalisis ragam dan beberapa data terkait mikroklimatik ammonia dan heat stress index (HSI) juga dihitung korelasinya untuk mengetahui hubungannya dengan performans broiler. Hasil penelitian menunjukkan bahwa perubahan mikroklimatik amonia signifikan menurukan performans ayam broiler, hal tersebut ditunjukkan dengan meningkatnya nilai FCR, penurunan konsumsi pakan, PBB, IP dan IOFC secara signifikan $(P \leq 0,05)$ mulai pada jarak $1 / 4$ panjang kandang dari inlet. Hasil analisis kolerasi menunjukkan adanya hubungan negatif dan signifikan antara performans dengan amonia, sebaliknya HSI tidak menunjukkan hubungan terhadap parameter yang diamati. Kesimpulan dari penelitian ini adalah peningkatan mikroklimatik amonia menurunkan performans ayam broiler di musim kemarau.
\end{abstract}

Kata Kunci : mikroklimatik amonia, , closed house, performans broiler, musim kemarau

\section{Introduction}

The dry season in Central Java is characterized by a rainfall below $100 \mathrm{~mm}$ (Edvin, 2000). The data from BMKG of Semarang Municipality for 2017 indicate that during dry season the average rainfall is $50-100 \mathrm{~mm}$. This macroclimate condition during the dry season has some contribution to the incoming air supply through the inlet into the closed house. The input temperature, relative humidity (Rh) and air velocity (AV) input variations are those factors causing the variation of ammonia volatilization rates within the closed house. Sarjana., et al (2017) research results show a significant correlation between humidity, $\mathrm{pH}$ litter and ammonia microclimatic change in the cage.

Microclimatic ammonia is a variant of microclimatic ammonia change inside the cage due to the contribution of different lighting, 
temperature, humidity, and air velocity (AV) (Soliman et al., 2017). Ammonia is one product of decomposition by bacteria from nitrogen waste which is not metabolized well such as uric acid and amino acid. The population distributin within the cage is usually technically divided based on pen placement and these results in varied distance change from the inlet, cage microclimate and ammonia accumulation. Previous research (Renata et al., 2018) finds that the further the distance from the inlet the higher the microclimatic ammonia state would be. Direct and continuous exposure of ammonia up to $25 \mathrm{ppm}$ results in respiratory tract irritation in mucosa part and decreased performance (Beker et al., 2004; Kristensen and Wathes, 2000; Patterson and Adrizal, 2005). At $5 \mathrm{ppm}$, ammonia can irritate the eyes greater than $10 \mathrm{ppm}$ it can be a stress trigger that it disrupts the eating activity in chicken and causes decreased feed consumption (Miles., et al, 2004). Meanwhile, in Beker et al., (2004) it is found that microclimatic ammonia at $50-70 \mathrm{ppm}$ significantly suppresses body weight (BW) 6-9\% and can even reduce body weight $17-20 \%$ in 7 weeks old chicken.

This research aims at investigating the effect of microclimatic ammonia change in a closed house on broiler's performance. The research hypothesis is there is an effect of microclimatic ammonia differences at increasingly further distance from the inlet on the Broiler's chicken's performance.

\section{Materials and Methods}

The research is conducted in a closed house of $60 \times 12 \mathrm{~m}^{2}$ size with a capacity of 11.000 chickens. The number of chickens used is 720 and their initial body weight is $49.25 \pm 1.13$ grams. The feeds used are S10, S11 and S12 with a nutrient content as presented in Table 1. S10 feed is used in 1-14 days old chickens, S11 in 1528 days old chickens and S12 is feed to 29-35 days old chicken. The tools used are ammonia detector to measure the microclimatic ammonia, kestrel to measure the micro air velocity, temperature, humidity and other tools used during the maintenance, namely hanging scale, feeders and drinkers.

The research is conducted using Randomized Group Design (RGD) consisting of 24 experiment units divided into 4 treatments and 6 groups. The treatment in this research is defined as the microclimatic ammonia change in the cage from the distance differences, as detailed below:

$\mathrm{T} 1$ = microclimatic ammonia measured at 0 of cage length $(0 \mathrm{~m})$ from the inlet

$\mathrm{T} 2=$ microclimatic ammonia measured at $1 / 4$ of cage length $(15 \mathrm{~m})$ from the inlet

$\mathrm{T} 3=$ microclimatic ammonia measured at $1 / 2$ of cage length $(30 \mathrm{~m})$ from the inlet

$\mathrm{T} 4=$ microclimatic ammonia measured at $3 / 4$ of cage length $(45 \mathrm{~m})$ from the inlet

Table 1. Nutritional Content of Rations

\begin{tabular}{lllll}
\hline \hline Food Substance & Content & \multicolumn{2}{c}{ Note } \\
\cline { 2 - 4 } & S10 & S11 & S12 & $\%$ \\
\hline Water Content* & 10.59 & 10.79 & 12.20 & $\%$ \\
Crude Fat* & 5.56 & 6.04 & 5.60 & $\%$ \\
Crude Fiber* & 4.94 & 6.32 & 5.57 & $\%$ \\
Crude Protein* & 20.22 & 19.31 & 18.27 & $\%$ \\
Ash* & 5.44 & 5.39 & 5.58 & $\%$ \\
Ca* $^{* *}$ & 1.08 & 1.16 & 0.91 & $\%$ \\
EM* & 3155 & 3122 & 3072 & \\
\hline Source & $:$ * Proximate analysis result & & \\
& $* *$ Based on calculation of Bolton formula as used in Sugiharto et al. (2017)
\end{tabular}


Table 2. Comparison of Macroclimate and Microclimate Condition during Research

\begin{tabular}{|c|c|c|c|c|c|}
\hline \multirow[t]{2}{*}{ Macroclimate } & \multicolumn{5}{|c|}{ Value } \\
\hline & \multicolumn{4}{|c|}{ Dry Season } & Rainy Season** \\
\hline Temperature $(\underline{\circ} \mathrm{C})$ & \multicolumn{4}{|c|}{29.62} & 25.64 \\
\hline Humidity (\%) & \multicolumn{4}{|c|}{64.83} & 88.61 \\
\hline Air velocity & \multirow{2}{*}{\multicolumn{4}{|c|}{2.10}} & 0.77 \\
\hline$(\mathrm{AV})(\mathrm{Km} /$ hour$)$ & & & & & \\
\hline Rainfall* (mm) & \multicolumn{4}{|c|}{$50-100$} & $100-150$ \\
\hline Microclimate & $\mathrm{T} 1$ & $\mathrm{~T} 2$ & T3 & T4 & \\
\hline Ammonia (ppm) & 1.42 & 2.67 & 4.28 & 6.36 & 4.02 \\
\hline Temperature $\left({ }^{\circ} \mathrm{C}\right)$ & 26.33 & 26.87 & 27.56 & 28.50 & 28.89 \\
\hline Humidity (\%) & 78.28 & 77.39 & 75.18 & 74.35 & 87.28 \\
\hline Air velocity $(\mathrm{AV})(\mathrm{km} / \mathrm{h})$ & 1.73 & 1.36 & 1.08 & 0.72 & 0.6 \\
\hline Heat Index & 157.68 & 157.76 & 156.79 & 156,83 & \\
\hline
\end{tabular}

Note: $*$ Meteorological, Climatological, and Geophysical Agency (BMKG, 2017)

**= Result of average microclimatic and microclimatic ammonia condition presented by the data in Renata et al., 2018

The broiler's chicken's performance is evaluated at the end of research when it is 35 days old. The parameters observed are feed consumption, body weight gain, FCR, performance index (PI) and Income Over Feed Cost (IOFC). The performance index is calculated using the equation used by Martins et al., (2016) as follows:

$$
\text { Performance index }(\mathrm{PI})=\frac{(100-\mathrm{D}) \times \mathrm{BW} \times 100}{\mathrm{FCR} \times(\mathrm{A} / \mathrm{U})}
$$

Note: $\mathrm{D}=$ Depletion (\%)

$$
\mathrm{BW}=\text { body weight }
$$$$
\mathrm{FCR}=\text { feed convertion ratio }
$$

$$
\mathrm{A} / \mathrm{U}=\text { average harvest age (days) }
$$

The data on average macroclimate and microclimate consisting of microclimatic ammonia, macro and micro temperature, humidity, rainfall, air velocity (AV)are taken at $05.00 \mathrm{am}, 1.00$ and $9.00 \mathrm{pm}$ in a 3 day interval.
The data on average macroclimate and microclimate are presented in the following table 2.

The obtained data are then subjected to analysis of variance. The correlation between the cage's microclimate condition \& ammonia's HSI value calculation and the performance parameters are also calculated to confirm the suspicion that microclimatic ammonia is the main determinator which influences the achievement of Broiler's performance. Heat stress index (HSI) is calculated based on the calculation between the high air temperature followed by high humidity and accumulation of heat radiation from both the surrounding and the chicken's activities. As an illustration, to find out the determination level of ammonia compared to several other factors on the performance a correlation analysis is made and presented in table 3.

Table 3. Correlation between microclimatic ammonia, $\mathrm{HSI}$ and the parameters observed

\begin{tabular}{lcc}
\hline \multirow{2}{*}{ Parameter } & \multicolumn{2}{c}{ rValue } \\
\cline { 2 - 3 } & Microclimatic Ammonia & HSI \\
\hline Feed consumption & $-0.810^{* *}$ & 0.281 \\
BWG & $-0.827^{* *}$ & 0.303 \\
FCR & $0.695^{* *}$ & 0.271 \\
IOFC & $-0.745^{* *}$ & 0.278 \\
\hline$* *=$ Correlation is significant at 1\% level & &
\end{tabular}


Table 4. Feed Consumption, BWG, FCR and IOFC

\begin{tabular}{lcccccc}
\hline \multicolumn{1}{c}{ Parameter } & $\mathrm{T} 1$ & $\mathrm{~T} 2$ & $\mathrm{~T} 3$ & $\mathrm{~T} 4$ & $\mathrm{P}$ & $\mathrm{SE}$ \\
\hline Feed consumption $(\mathrm{kg})$ & $3223.83^{\mathrm{a}}$ & $3159.22^{\mathrm{b}}$ & $3098.69^{\mathrm{c}}$ & $3015.55^{\mathrm{d}}$ & 0.001 & 0.001 \\
BWG (kg) & $1844.54^{\mathrm{a}}$ & $1710^{\mathrm{b}}$ & $1665^{\mathrm{bc}}$ & $1561.33^{\mathrm{c}}$ & 0.001 & 0.008 \\
FCR & $1.59^{\mathrm{b}}$ & $1.67^{\mathrm{ab}}$ & $1.67^{\mathrm{ab}}$ & $1.73^{\mathrm{a}}$ & 0.030 & 0.030 \\
Performance Index & $382.82^{\mathrm{a}}$ & $340.70^{\mathrm{b}}$ & $331.64^{\mathrm{bc}}$ & $303.79^{\mathrm{c}}$ & 0.001 & 11.420 \\
IOFC & $12271.6^{\mathrm{a}}$ & $10336.9^{\mathrm{ab}}$ & $9982.7^{\mathrm{b}}$ & $8743.10^{\mathrm{b}}$ & 0.008 & 0.032 \\
\hline
\end{tabular}

The correlation between cage's microclimatic condition and ammonia toward the performance parameters indicates that there is a significant influence of microclimatic ammonia change on the chicken's performance, and HSI value has insignificant influence on performance decrease. In general, the performance parameters show a negative correlation, meaning that the increase in microclimatic ammonia will be responded to by a performance decrease, and HSI shows no fairly significant impact.

\section{Results And Discussion}

Based on the analysis of variance, microclimatic ammonia significantly $(P \leq 0.05)$ decreases feed consumption, Body weight gain (BWG), Performance index (PI), Income Over Feed cost (IOFC) and FCR begins to increase $(P \leq 0.05)$ in $T 2$. The data are presented in Table 4

\section{Feed consumption}

Significant feed consumption decrease at further distance from the inlet is suspected to be influenced by the increase of microclimatic ammonia by $46.81 \%$ which begins to occur at a distance of $1 / 4$ of cage length, and at distances of $1 / 2$ and $3 / 4$, increases by $65.65 \%$ and $77.67 \%$ respectively occur. During this dry season the occuring increase of microclimatic ammonia is still lower than during the rainy season (Renata et al, 2018), nevertheless it has had significant effect on the feed consumption decrease.

The comparison of cage's microclimate condition during dry and rainy seasons is presented in illustration 1 . What needs to be noted is that the microclimate inside the cage which is managed by a control panel is expected to also have some contribution to the microclimatic ammonia change in different seasons. During the dry season, the cage's absolute temperature is higher than during the rainy season, thus the automatic panel control "Rotem" we use in this research cage will make some adjustment by increasing the air velocity. This will automatically influence the ammonia elimination rate. This explains why the microclimatic ammonia is lower during dry season, in addition to the contribution of microclimate condition in the form of lower Rh than during rainy season. The lower Rh results in the chance for lower ammonia volatilization. Result of Sarjana et al., (2017) research indicates that humidity litter and microclimatic ammonia has a fairly strong correlation: 


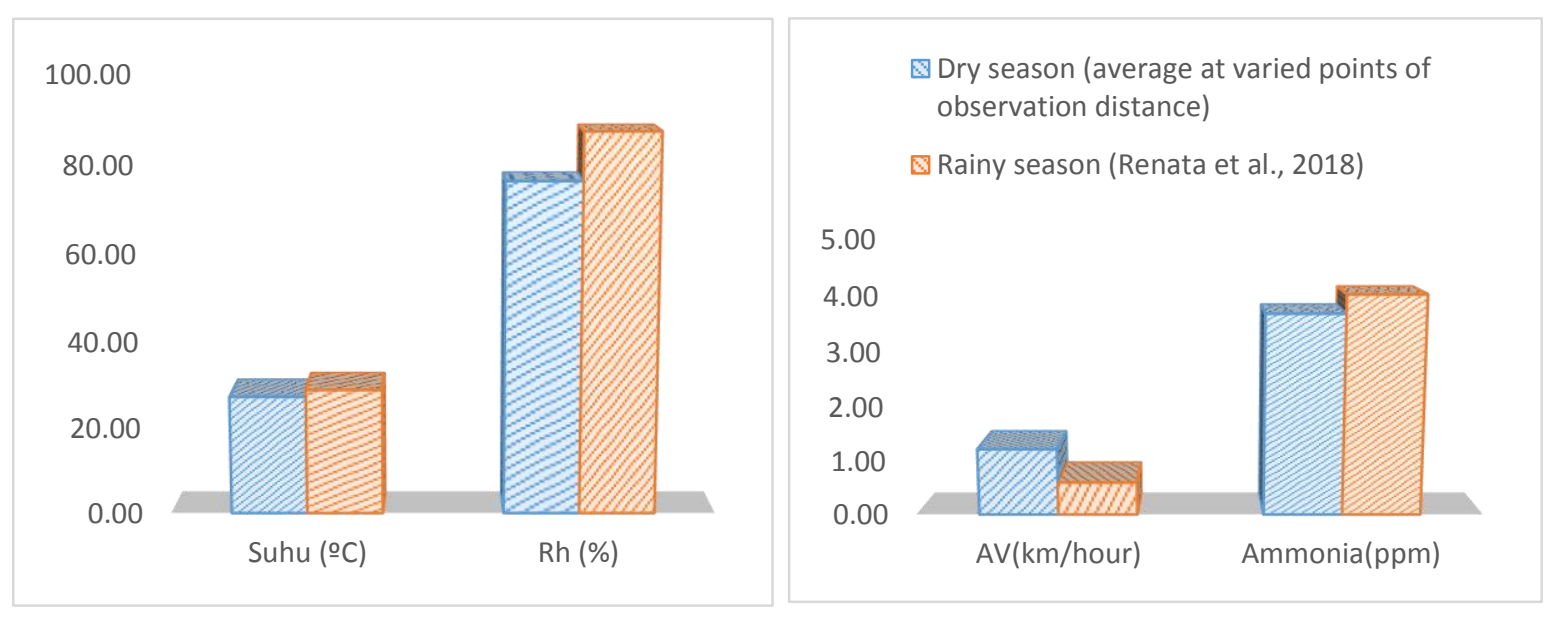

Figure 1. Comparison between average cage's microclimate condition and microclimatic ammonia during dry and rainy seasons.

Referring to table 3, it turns out the cage's microclimate change in this research which is observed based on HSI calculation is not the main factor which causes the feed consumption decrease. The increase in microclimatic ammonia in this research has greater contribution than HSI in decreasing the feed consumption. The microclimatic ammonia increase from $1.42 \mathrm{ppm}$ to $2.67 \mathrm{ppm}$ begins to decrease the feed consumption significantly by $2 \%$. The increased microclimatic ammonia raises the chance for irritation in respiratory tract to occur, particularly at parabronchi. Beker et al., (2004); Patterson and Adrizal's (2005) studies indicate that ammonia increase results in performance decrease and it is followed by irritation in respiratory tract. This irritation in parabronchi resulting from ammonia will cause pulmonary vascular disorders and low oxygen uptake followed with oxidative stress (Wideman et al., 2013). Based on the foregoing, the feed consumption decrease in this research is suspected to result from the oxidative stress increase.

The irritation in respiratory tract is also suspected to result in heat loss inefficiency. This heat loss inefficiency is respond by the poultry by panting in order to dispose of heat and reduce feed consumption as a source of heat. This confirms Charles and Payne (1966); Yahav
(2004); and Tamzil's (2014) studies which find that an increase in microclimatic ammonia will disrupt the poultry's heat release, thus resulting in decreased panting efficiency, decreased feed consumption and increased water intake. Kusnadi and Rahim (2009) and Ximenes et al., (2018) research results also show that an increase in body temperature causes a decrease in triiodothyronine $\left(T_{3}\right)$ hormone production, thus it affects the mechanism of hormonal performance which plays a part in metabolic rate. In this research, the decreased metabolic rate causes decreased feed consumption.

It is suspected that the decreased metabolic rate is due to two causes, namely oxygen uptake inefficiency resulting from damage to the respiratory tract and decreased oxygen availability as a result of accumulated utilization in previous pens closer to the inlet. The decreased oxygen uptake and availability are suspected to cause decreased amount of oxygen consumption and it is followed by decreased metabolic rate. Isroli and Listyorini's (2004) research indicates that oxygen consumption is one of those factor which influence metabolic rate.

\section{Body Weight Gain (BWG) and Feed Convertion Ratio (FCR)}

The lower body weight gain and increased FCR value as a result of microclimatic ammonia 
increase in this research are significant and suspected to be influenced by 2 things. Firstly, the negative impact of microclimatic ammonia in decreasing feed consumption thus it automatically decreases protein consumption. The decreased protein consumption results in lower BWG and high FCR value. Suthama et al., (2006) and Eits et al., (2002) find that growth is determined by the amount of protein and energy consumed, thus lower protein consumption causes lesser amount of protein deposition through protein synthesis hence the body weight gain and FCR achievements are not optimal.

Secondly, it is caused by the increase in oxidative stress stemming from increased oxidative stress as a result of respiratory tract irritation and the decreasingly lower oxygen uptake as explained above reduces the metabolic rate thus the protein deposition is lesser. In Wideman et al. (2013) research, it is found that the damage to lungs organ due to increased microclimatic ammonia will leads to greater oxidative stress, hence it causes the metabolic rate to decrease and further results in the decreasingly lower body weight gain achievement and FCR achievement inefficiency. Another study by Miles et al., (2004) finds that an increase in microclimatic ammonia by 25 ppm could cause weight loss by $2 \%$. Bell and Weaver (2002) suggest that the factors influencing FCR value are microclimatic ammonia, temperature change, lighting, feeding and drinking water consumption.

\section{Performance Index (PI) and Income Over Feed Cost (IOFC)}

The observation point at further distances from the inlet results in decreased performance index and IOFC. Based on the result of analysis of variance, the performance index ranges from 303.79 to 382.82 . Performance index value below 351 shows less satisfactory maintenance success.Santoso and Sudaryanti (2009) states that a farm has an excellent maintenance success if the performance index standart is between 351 and 400. IOFC calculation is used to find out the profit to be obtained by the farmer from the amount of feed spent. The higher the microclimatic ammonia the lesser the profit achievement. The microclimatic ammonia increase in this research is $25.87 \%$, decreases $7,35 \%$ of performance index achievement and IOFC by $10.51 \%$. According to Yamin (2008) the high IOFC value is significantly determined by the body weight gain produced and the efficiency of feed utilization by the Broiler's chicken. Gudev et al., (2011) in previous research finds that an increase in microclimatic ammonia from 25 to $80 \mathrm{ppm}$ leads to greater production costs, therefore the profit obtained is lower.

\section{Conclusion}

The conclusion of this research is the higher the microclimatic ammonia at increasingly further distances from the inlet the lower the Broiler's chicken's performance.

\section{Acknowledgment}

The writer would like to thank the Faculty of Animal and Agricultural Sciences of Diponegoro University for providing the facilities in the form of closed house cage and Broiler's chicken material during the research.

\section{References}

Beker, A., S. L. Vanhooser, J. L. Swartzlander, dan R. G. Teeter. 2004. Atmospheric ammonia concentration effects on broiler growth and performance. J. Appl. Poult. Res. 13 : 5-9.

Bell, D. D., dan W. D. Weaver, Jr. 2002. Commercial Chicken Meat and Egg Production. 5th edition. Springer Science and Business Media Inc. New York.

Charles, D. R dan C. G. Payne.1966. The influence of graded levels of atmosphericammonia on chickens. British Poultry Science. 7 (3) : 177-187.

Edvin, A. 2000. Pola hujan rata-rata bulanan wilayah indonesia; tinjauan hasil kontur data penakar dengan resolus- echam t-42. Jurnal Sains \& Teknologi Modifikasi Cuaca. 1 (2) : 113-123 
Eits, R.M., R. P. Kwakkel, M. W. A. Verstegen, P. Stoutjesdijk, and K. H. De Greef. 2002. Protein and lipid deposition rates in male broiler chickens: separate responses to amino acids and proteinfree energy. Poultry Science. 81:472-480

Gudev, D. S. Papova-Rachelva. I. Lanchev. P. Moneva. 2011. Effect of Betaine and Air Ammonia Concentration On Broiler Performance, Plasma Corticosterone Level, Lymphoid Organ Weights and Some Haematological Indices. Biotechnology in Animal Husbandry 27 (3): 687-703Indonesian Meteorological, Climatological, and Geophysical Agency. 2017. Informasi Curah Hujan Bulanan. http://www.bmkg.go.id/tag/?tag=informasihujan-bulanan\&lang=ID. Accessed on $3^{\text {rd }}$ November 2018.

Isroli, H. Pratikno, dan R. H. Listyorini. 2004. Pengaruh intensitas dan lama cekaman panasterhadap laju metabolisme dan konsumsi oksigen pada ayam broiler periode starter. J.Indon.Trop.Anim.Agric.29 (3) : 161-165.

Kristensen, H. H. dan C. M. Wathes. 2000. Ammonia and poultry welfare: a review. World's Poultry Science Journal. 56 (3): 235 - 245.

Kusnadi, E dan F. Rahim. 2009. Performa dan kandungan triiodotironin plasma ayam broiler akibat pengaruh cekaman panas di daerah tropis. Media Peternakan. 32 (3) : 155-162.

Miles, D. M., S. L. Branton dan B. D. Lott. 2004. Atmospheric ammonia is detrimental to the performance of modern commercial broilers. Poultry Science. 83 : 1650-1654.

Patterson, P. H. \& Adrizal. 2005. Management strategies to reduce air emissions: Emphasis dust and ammonia. J. Appl. Poult. Res. 14 : 638650.

Renata, T.A Sarjana dan S. Kismiati. 2018. Pengaruh zonasi dalam kandang closed house terhadap kadar amonia dan dampaknya pada kualitas daging broiler di musim penghujan. Jurnal IImuilmu Peternakan. 28 (3) : 183-191.
Soliman E.S, S.A Moawes, dan R. A Hassan. 2017. Influence of microclimatic ammonia levels on productive performance of different broilers' breeds estimated with univariate and multivariate approaches. J. Vet. World. 10 (8) : 880-887

Sarjana, T. A., L. D. Mahfudz, M. Ramadhan, Sugiharto, F. Wahyono, dan S. Sumarsih. 2017. Ammonia emission and litter condition of broiler reared in conventional open housing system feed different additive inclusion and its combination in ration Prosiding seminar Nasional Pengembangan Peternakan Berkelanjutan 9. 15 November 2017. Sumedang, Indonesia.

Sugiharto, S., T. Yudiarti and I. Isroli. 2017. Effect of feeding cassava pulp fermented with Acremonium charticola on growth performance. Nutrient digestibility and meat quality of broiler chicks. Journal of Animal Science, South African. Vol 47 (2): 130-138.

Suthama, N. 2006. Kajian aspek "protein turnover" tubuh pada ayam kedu periode pertumbuhan. Media Peternakan. 29 (2) : 47-53

Tamzil, M. H. 2014. Stres panas pada unggas : metabolisme, akibat dan upaya penanggulangannya. Wartazoa. 24 (2) : 57-66

Wideman, R.F, D.D Rhoads, G.F Erf dan N.B Anthony. 2013. Pulmonary arterial hypertension (ascites syndrome) in broilers: A review. Poultry Science $92: 64-83$.

Ximenes, L., P. Trisunuwati dan Muharlien. 2018. Levels of hormones triiodothyronine and plasma blood glucose broiler starter due to heat stress and preliminary difference feeding time. International Journal Of Research. 6 (Iss.1) :421427.

Yahav, S. 2004. Ammonia affects performance and thermoregulation of male broiler chickens. Animal Research. 53 : 289-293

Yamin, M. 2008. Pengaruh tingkat protein ransum terhadap konsumsi, pertambahan bobot badan dan IOFC ayam pedaging. Jurnal Agro. 9 (3) : 1320. 